\title{
Modification of Manual Raindrops Type Observatory Ombrometer with Ultrasonic Sensor HC-SR04
}

\author{
Anton Yudhana ${ }^{1}$, Jessy \\ Rahmayanti ${ }^{2}$, Son Ali Akbar ${ }^{3}$ \\ Electrical Engineering Department \\ Universitas Ahmad Dahlan \\ Yogyakarta, Indonesia
}

\author{
Subhas Mukhopadhyay ${ }^{4}$ \\ Mechanical / Electronic Engineering \\ Macquaire University \\ NSW, Australia
}

\author{
Ismail Rakip Karas ${ }^{5}$ \\ Computer Engineering Department \\ Karabük University \\ Karabük, Turkey
}

\begin{abstract}
Water, in any way it comes, is important for the life of all living things. Indonesia is an area of tropical equatorial with a variation of rain, which is quite high. The regularity of the distribution of rainfall is one of the aspects most important to the activity of the community. As the development of technology, the intensity of rainfall can be measured manually using Ombrometer Observatory tool. The manual tool for measuring the rain precipitation, Ombrometer Observatorium, is used to take data manually. Samples should be taken at 7.00 a.m. everyday using a measuring cup to know the height of the water contained. However, the type is prone to error at the high rainfall intensity, since the drainage of the samples is conducted every 24 hours. Therefore, much water is wasted. To solve the problem, a modification of a rainfall gauge was made, that is Ombrometer Observatory with ultrasonic sensor HC-SR04. The height of the water in the container is sent through a server of which the data is stored in the database every ten minutes to reduce the risk of evaporation. It also minimizes the error in measuring the rainfall intensity. The results have been compared to the ones by BMKG (Meteorology, Climatology, and Geophysics Agency). The correlation value of the measurement ratio reached 0.9739 or $97.39 \%$.
\end{abstract}

Keywords-Observatory Ombrometer; rainfall; database; ultrasonic sensor; IoT; rain gauge

\section{INTRODUCTION}

Water plays significant role for the life of all living things on earth. Water is the essence of life and essential nutrients for humans, animals, plants, and the environment [1]. Water that comes from rain can meet the daily needs of any living things. For example, water is a part of community livelihoods as well as irrigation for farmers [2][3][4]. Farmers also need water to determine the quality of the soil as a planting medium [5]. Water and soil quality on agricultural land is very important to determine the types of plants suitable for planting [6]. Water that has good quality is the one that is not too polluted by chemicals [6],[7].

Related to water is the climate. The two main elements of climate formation are temperature and rainfall. Temperatures that have relatively high or low values of water vapor will produce certain humidity [8]. The impact of extreme climate change will cause an irregular change of seasons and ecological disasters, such as floods and long droughts, that may lead to losses [9],[10]. Indonesia lies in a tropical equator with high rainfall variation [11]. The regularity of rainfall patterns and distribution in an area is an important aspect of the ongoing activities of certain sectors of society [12]. Rainfall shows spatial structure in the form of closed contours in statistics [13]. Rainfall data is very useful for areas relying on agriculture and urban management [14]. High rainfall that exceeds the capacity of nature can cause disasters, such as floods [15].

Various ways have been conducted to overcome disasters due to high rainfall intensity, such as environmental management by increasing water infiltration and irrigation. Water absorption systems to reduce the vulnerability of disasters can neither accommodate in the event of extreme rainfall [16]. The need for a hydrological information system regarding water resource management has been regulated in Law No. 7 of 2004. The appendix to the Presidential Regulation of the Republic of Indonesia Number 28 of 2012 concerning Management Policies on Hydrology, Hydrometeorology, and Hydrogeology at the national level, mentions that hydrological data that is accurate, correct, sustainable, and timely is one of the factors that determine the implementation of resource management optimal water.

As technology develops, rainfall intensity can be measured automatically using an instrument called Automatic Rain Gauge (ARG). Several types of rain gauges have been developed, such as weighing gauges, capacitance gauges, tipping-bucket (TB) gauges, optical gauges, disdrometers, underwater acoustic sensors, and others [17]. Estimating the rainfall is necessary to estimate the rainfall data of an area[18]. In the Meteorology Climatology and Geophysics Agency in several areas, to get rainfall data, two types of equipment are used, namely Ombrometer Observatory (OBS) and Hellman and Tipping Bucket. Manual rain gauges are the type of rain gauge of which the data are not recorded, while the automatic rain gauge Hellman and Tipping Bucket do the opposite. In the rain gauge, the Tipping Bucket type is connected to a logger that will count each end of the rainwater that enters the rainfall gauge. Rainfall data will be sent automatically to the server during a rain event and every 24 hours with the help of sensors [19][20][21].

At weather stations in Indonesia, a manual type Observatory Ombrometer is often installed in a tool park to estimate the season in an area [22]. Observatory Ombrometer rain gauge is widely used in Indonesia because it is considered 
easier to operate and has a very economical price compared to other types of rain gauge.

The weakness of Observatory Ombrometer rain gauge is that the reading of rainfall data is still done manually using a measuring cup that is vulnerable to an error in reading the samples at high rainfall intensity. In the event of rain with high intensity, this type of manual tool cannot collect rainwater, because of the overflowing water in the cup. This condition will hamper the process of measuring rainfall if there is more than one rain event in a day, keeping in mind that the data collection and drainage of the container in the Observatory Ombrometer type rainfall gauge is only conducted every 24 hours at $07.00 \mathrm{am}$.

The solution to this problem is the manufacture of a manual rainfall gauge Ombrometer Observatory using the HCSR04 ultrasonic sensor that will change the data collection automatically without using a measuring cup. In addition, the drainage of water in the tube will also be modified automatically by adding valves and relays.

The HC-SR04 ultrasonic sensor is a sensor that uses sonar to determine the distance to an object. This sensor has pretty good accuracy and a fairly stable reading. Operations are not influenced by sunlight or dark-colored material but are influenced by acoustic material. This sensor has a specification ranging from $2 \mathrm{~cm}$ to $400 \mathrm{~cm}$ with a resolution of $0.3 \mathrm{~cm}$, and an angle range of less than 15 degrees which will minimize data retrieval errors during high rainfall, in which the tube can no longer hold water [23].

\section{RESEARCH METHOD}

\section{A. Hardware Research Tools}

In the modified schematic circuit of Fig. 1, it is explained that the input voltage of the rain gauge modifier is $12 \mathrm{~V}$. At the $12 \mathrm{~V}$ input, voltage will be supplied to the DC-DC step-down module so that the output voltage from the step-down raise from $7 \mathrm{~V}$ to $9 \mathrm{~V}$. The output voltage from the step-down will be supplied to the Arduino input voltage. It is used to adjust the reference voltage of the Arduino specification. The voltage sensor is used to determine the remaining capacity of the input voltage source [24].

The HC-SR04 ultrasonic sensor is connected to Arduino to find out the range of water level held in the rain gauge. The results of the water level range will be displayed on the LCD.

If the range of water level detected by the HC-SR04 ultrasonic sensor reaches $10 \mathrm{~cm}$ and the RTC DS3231 on the circuit schematic that functions as a real-time indicator has shown at 07.00 Western Indonesian Time, the ultrasonic sensor gives instructions to Arduino to send signals to the relay to start the pump to drain for 2 minutes 30 seconds. Realtime time generated by RTC DS3231 will be displayed on the LCD.
Data transmission to the ceerduad.com website platform is carried out with the help of the ESP8266 wifi module, which is communicated with Arduino. The data transmission is carried out in two conditions. The first is once every 10 minutes until 07.00 WIB to reduce evaporation in the event of extreme hot weather. Second is when the water stored in the rain gauge has been detected by an ultrasonic sensor HC-SR04 as high as $10 \mathrm{~cm}$. Drain on the container is carried out at a height of $10 \mathrm{~cm}$ or $100 \mathrm{~mm}$ because it is adjusted to the maximum range in the value of low rainfall intensity, between $0 \mathrm{~mm}-100 \mathrm{~mm}$.

\section{B. Software Research Tools}

Overall, the software used in this study is Arduino IDE Fig. 2. Rainfall data will be sent to the website www.mhs.ceerduad.com in Fig. 3 through the Wifi Module.

- Platform Ceerduad: The ceerduad platform is an IoT platform service that is communicated using TCP / IP Fig. 3 using the data posting method and uses the PHP programming language to receive, store, and process the data to display graphics.

- System Work Principle:In general, the system consists of a controller in the form of an Arduino IDE, an HCSR04 ultrasonic sensor, a wifi module that is used as a data sender, and a power supply in the form of a $12 \mathrm{~V}$ battery. Block diagram of the system is shown in Fig. 4:

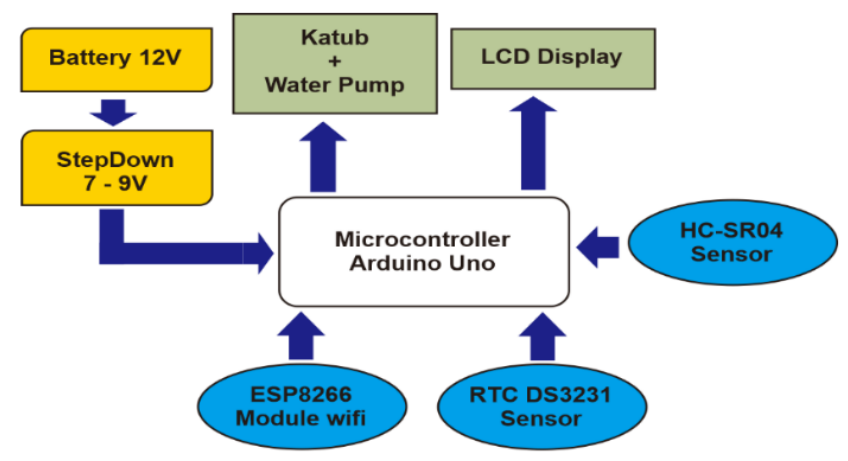

Fig. 1. Block Diagram of Hardware.

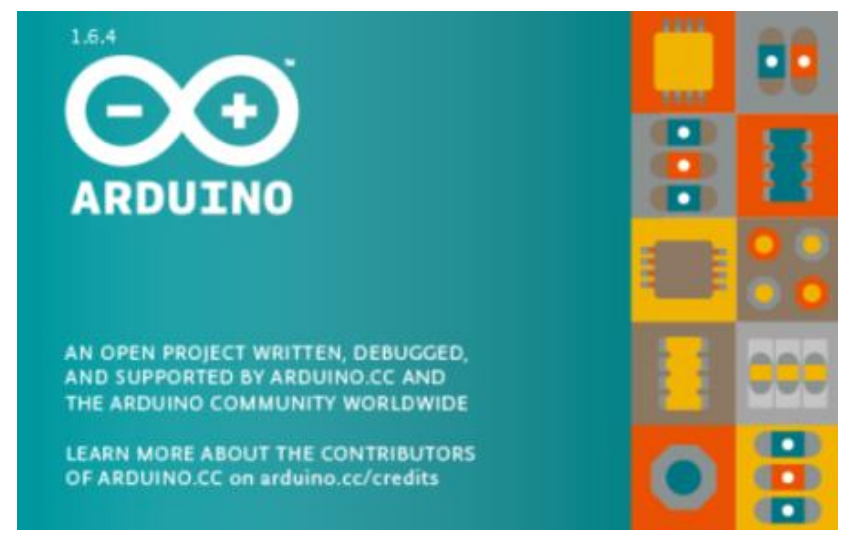

Fig. 2. Arduino IDE. 


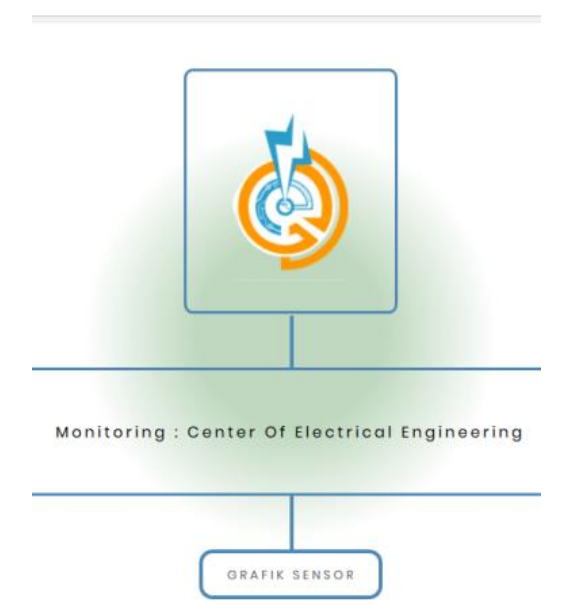

Fig. 3. Server Display Ceerduad.

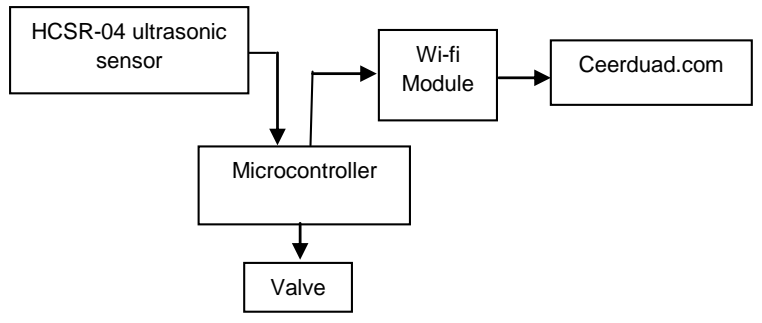

Fig. 4. Block Diagram of the System.

The basic principle of this Observatory Ombrometer type manual rain gauge modification tool is the HC-SR04 ultrasonic sensor which has been set to detect the height of the water in the reservoir when filled with rainwater, then the signal from the HC-SR04 Ultrasonic sensor will send data to the microcontroller. In the microcontroller, the data will be processed and sent by the computer through the wifi module and at the same time, the drain valve will open due to the signal from the microcontroller. As mentioned previously the system works in two condition: every day at 7.00 a.m. and when the water reaches the sensor.

\section{RESUlTS AND DISCUSSION}

Rainfall intensity has several specifications shown in Table I.

To measure the height of water in a tube the formula is used:

$H=\frac{\text { Volume }}{\text { Cross-sectional area }}$

With

$\mathrm{H}=$ Water level

TABLE. I. RAINFALL SPECIFICATIONS

\begin{tabular}{|l|l|}
\hline Rain Category & Rainfall / Day $(\mathrm{mm})$ \\
\hline Low & $0-100$ \\
\hline Intermediate & $100-300$ \\
\hline High & $300-500$ \\
\hline Very high & $\geq 500$ \\
\hline
\end{tabular}

With a program as stated in Pseudocode 1:

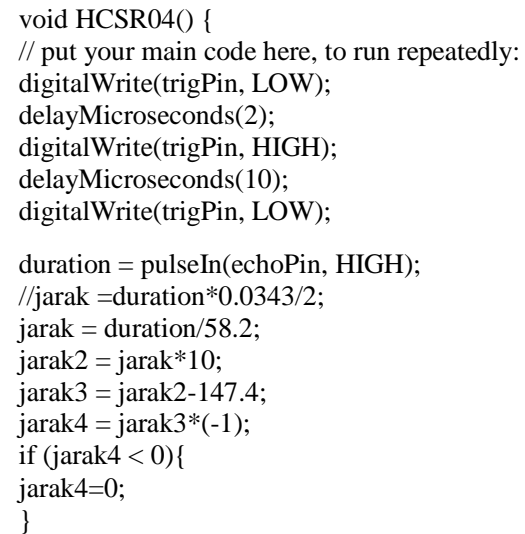

Pseudocode. I. Data Retrieval Function HC-SR04

- Tool Development: In the design of the modified form of an ombrometer observatory type manual rain gauge is on a container that has a height of $26.5 \mathrm{~cm}$ with a diameter of a $15 \mathrm{~cm}$ funnel. In the modification tool, the reservoir tube is coated with styrofoam and the outer layer is coated using aluminum foil. This is to reduce the evaporation of the floating water during extreme heat or drought.

Inside the reservoir tube, there is an HC-SR04 ultrasonic sensor placed on the radius of the tube to minimize sensor reading errors. Just below the reservoir tube is a beam that is used as a place to store various circuits such as mini-systems, pumps, adapters, and batteries.

The results of the water level read by the ensors that will be sent to the online database server, which then displayed on the LCD offline. On the LCD, several buttons are used to switch on / off, and reset, to check the water level and the Internet connection [25]. The LED located next to the LCD is used as an indicator when the instrument is being operated and as an indicator when the instrument is draining the tubes. The modification system design can be seen in Fig. 5 .



Fig. 5. Tool Development. 
TABLE. II. COMPARISON RAINFALL SPECIFICATIONS

\begin{tabular}{|l|l|l|l|l|}
\hline $\begin{array}{l}\text { Days } \\
\text { to }-\end{array}$ & $\begin{array}{l}\text { Date month } \\
\text { Year }\end{array}$ & $\begin{array}{l}\text { Manual } \\
\text { Measurement } \\
(\mathrm{mm})\end{array}$ & $\begin{array}{l}\text { Modification } \\
\text { Measurement } \\
(\mathrm{mm})\end{array}$ & $\begin{array}{l}\text { Rainfall } \\
\text { Intensity }\end{array}$ \\
\hline 1 & 26 April 2019 & 0 & 0 & Low \\
\hline 2 & 27 April 2019 & 0 & 0 & Low \\
\hline 3 & 28 April 2019 & 17.1 & - & Low \\
\hline 4 & 29 April 2019 & 76.5 & 73.2 & Low \\
\hline 5 & 30 April 2019 & 3.2 & - & Low \\
\hline 6 & 1 May 2019 & 0 & 0 & Low \\
\hline 7 & 2 May 2019 & 6.4 & 3 & Low \\
\hline 8 & 3 May 2019 & 0 & 1 & Low \\
\hline 9 & 4 May 2019 & 0 & 1 & Low \\
\hline
\end{tabular}

- Measurement Analysis Data: The measurement results obtained using the BMKG manual with modifications using the HC-SR04 ultrasonic sensor are as follows which are listed in the Table II.

Fig. 6 shows relatively small value of the rainfall. From the results of the comparison of measurements of manual tools with modified tools, the correlation value reached $97.39 \%$.

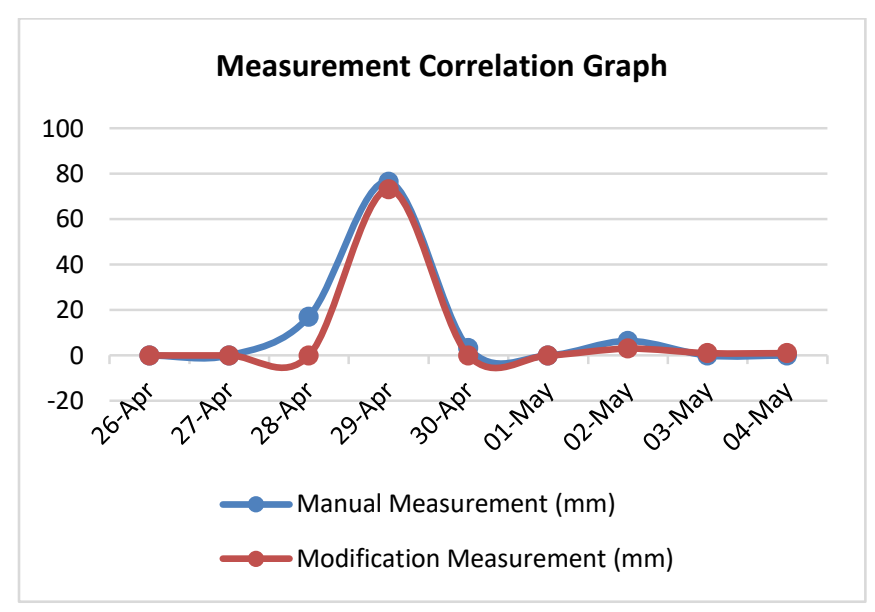

Fig. 6. Measurement Correlation Graph.

\section{CONCLUSION AND SUGGESTION}

To conclude, sending the rainfall data in the field can be conducted automatically using the Wi-Fi ESP8266 module. The concept works successfully. Based on the data and the comparison with those by BMKG, the correlation of rainfall measurement reached the $07.39 \%$.

To get optimal and stable values, it is necessary to replace sensors with a higher level of accuracy. This will reduce the error factor in reading the data. Also, the addition of an SD card is needed to handle data storage if the data is not sent successfully on the server due to the lack of internet network.

\section{ACKNOWLEDGMENT}

Acknowledgments are given to LPPM UAD for providing PKLN 2019 research funds with contract numbers PKLN-PI001/SP3/LPPM-UAD/IV/2019.

\section{REFERENCES}

[1] M. A. Yunus And S. C. Mukhopadhyay, "Development Of Planar Electromagnetic Sensors For Measurement And Monitoring." IOP Publishing, Pp.01-09, 2017.

[2] A. Yudhana And A. C.Kusuma, I. O. P. C. Series And M. Science, "Water Quality Monitoring At Paddies Farming Based On Android," IOP Conference Series: Materials Scient and Engineering, Vol. 1, Pp.0913, 2018.

[3] Sunardi, S. A. Akbar, F. Noviyanto, E. Wibowo, And R. Naufal, "Irigation Distribution Automatization Based On Scheduling System," Iop Conf. Ser. Mater. Sci. Eng., Vol. 403, No. 1, 2018.

[4] S. A. Akbar, Sunardi, Harianto, And F. Noviyanto, "Irrigation Distribution System For Agriculture Using Fuzzy Control And AndroidBased Water Monitoring," In Proceedings Of The 2019 Ahmad Dahlan International Conference Series On Engineering And Science (Adics-Es 2019), 2019, Vol. 189, Pp. 45-49.

[5] A. Yudhana And S. A. Akbar, "Kelompok Tani Desa Argorejo," Pp. 298-302.

[6] U. Syafiqoh And A. Yudhana, "Pengembangan Wireless Sensor Network Berbasis Internet Of Things Untuk Sistem Pemantauan Kualitas Air Dan Tanah Pertanian," Jurnal Pengembangan IT (JPIT), Vol.03, No. 02, Pp. 285-289, 2018.

[7] Menteri Kesehatan Republik Indonesia, "Peraturan Menteri Kesehatan Nomor: 416 / Men . Kes / Per / Ix /1990 Tentang Syarat-Syarat Dan Pengawasan Kualitas Air,” Pp. 1-10, 1990.

[8] J. Ascorbe, J. Corres, F. J. Arregui, I. R. Matias, And S. C. Mukhopadhyay, "High Sensitivity Optical Structures For Relative Humidity Sensing," Pp. 55-79.

[9] B. H. N. Ryke Nandini, "Kajian Perubahan Curah Hujan, Suhu Dan Tipe Iklim Pada Zone Ekosistem Di Pulau Lombok (Study Of Rainfall, Temperature And Type Of Climate Change In Lombok Island Ecosystem Zone)," Jurnal Kebijakan Kehutanan, No. August 2017, Pp. 228-244, 2011.

[10] L. Warlina, "Pencemaran Air: Sumber, Dampak Dan Penanggulangannya," Pp. 1-26, 2004.

[11] E. Hermawan, "Pengelompokkan Pola Curah Hujan Yang Terjadi Di Beberapa Kawasan Pulau Sumatera Berbasis Hasil Analisis Teknik Spektral,” J. Meteorol. Dan Geofis., Vol. 11, No. 2, Pp. 75-85, 2010.

[12] W. Estiningtyas "Penentuan Wilayah Kunci Keragaman Iklim Indonesia Menggunakan Indikator Global untuk Mendukung Adaptasi Perubahan Iklim" J. Agromet Indonesia, Vol. 21, No. September, Pp. 1669-1672, 2006.

[13] C. Enjamio, E. Vilar, F. P. Fontan, A Redaño, And D. Ndzi, "Dimensions And Dynamic Evolution Of Microscale Rain Cells," No. 1, 1999.

[14] C. Jing, M. Du And Et Al, "Research On Accuracy Assessment Of Urban Rainfall Spatial Interpolation From Gauges Data School Of Geomatics And Urban Spatial Information Of Beijing University Of Civil Engineering And Architecture, Beijing, China Key Laboratory For Urban Geomatics Of National Administration Of Surveying, Mapping And Geoinformation, Beijing, China," IEEE Geoscience And Remote Sensing Symposium, Pp. 3121-3124, 2014.

[15] A. Muliantara, N. Agus, And S. Er, "Perancangan Alat Ukur Ketinggian Curah Hujan Otomatis Berbasis Mikrokontroler," J. Ilm. Ilmu Komput., Vol. 8, No. 2, Pp. 31-37, 2015.

[16] P. Willems And J. Olsson, "Climate Change Impact Assessment On Urban Rainfall Extremes And Urban Drainage: Methodologies And," Change, Vol. 6, No. 1, Pp. 149-154, 2009.

[17] E. Habib, W. F. Krajewski, And Et Al, "Sampling Errors Of Tipping Bucket Rain Gauge Measurements” No. April, Pp. 159-166, 2001.

[18] U. Lewlomphaisarl And P. Saengsatcha, "High Accuracy Tipping Bucket Rain Gauge," Proceedings of SICE Annual Conference (SICE), Pp. 372-375, 2012.

[19] W. Bunganaen, “Analisis Hubungan Tebal Hujan Dan Durasi Hujan Pada Stasiun Klimatologi Lasiana Kota Kupang," Jurnal Teknik Sipil, Vol. Ii, No. 2, Pp. 181- 190, 2013. 
[20] T. Karuturi And V. Raghava, "Internet Enabled Tipping Bucket Rain Gauge," International Conference on Computer Communication and Informatic, Pp. 1-5, 2014.

[21] M. D. Amico, S. L. Jong, And C. Riva, "Tipping Bucket Data Processing For Propagation Application," Electrobic Letters, Vol. 49, No. 8, Pp. 49-51, 2013.

[22] Sunarno, "Rancang Bangun Sistem Pengukur Curah Hujan Jarak-Jauh Real Time Sebagai Peringatan Banjir Lahar Dingin," Forum Tek., vol. 33, pp. 175-180, 2010.
[23] U. M. Arief, "Pengujian Sensor Ultrasonik PING untuk Pengukuran Level Ketinggian dan Volume Air," J. Ilm. "Elektrikal Enjiniring" UNHAS Vol. 9 No. 2 Mei-Agustus 2011, vol. 9, no. 2, pp. 72-77, 2011.

[24] A. Yudhana And J. Rahmawan, "Eontex Conductive Strechtable Sensor Response On Smart Glove For Sign Language," Ahmad Dahlan Conference Series on Engineering and Science (ADICS-ES 2019), Vol. 189, Pp. 22-25, 2019.

[25] A. Yudhana and H. S. Purnama, Proyek Instrumentasi Medis Berbasis Internet of Things. 